МОДЕЛЮВАННЯ ВПЛИВУ ІНТЕГРАЛЬНОГО ПОКАЗНИКА ФОРМУВАННЯ ТА ВИКОРИСТАННЯ ІНТЕЛЕКТУАЛЬНОГО КАПТТАЛУ НА УЗАГАЛЬНЮЮЧІ КРИТЕРІЇ КОНКУРЕНТОСПРОМОЖНОСТІ Й ІНВЕСТИЦЙНОЇ ПРИВАБЛИВОСТІ БУДІВЕЛЬНИХ ПІДПРИЕМСТВ

\title{
SIMULATION OF THE INFLUENCE OF THE INTEGRAL INDICATOR FOR FORMATION AND USE OF INTELLECTUAL CAPITAL ON THE GENERALIZED CRITERION OF COMPETITIVENESS AND INVESTMENT ATTRACTIVENESS OF CONSTRUCTION COMPANIES
}

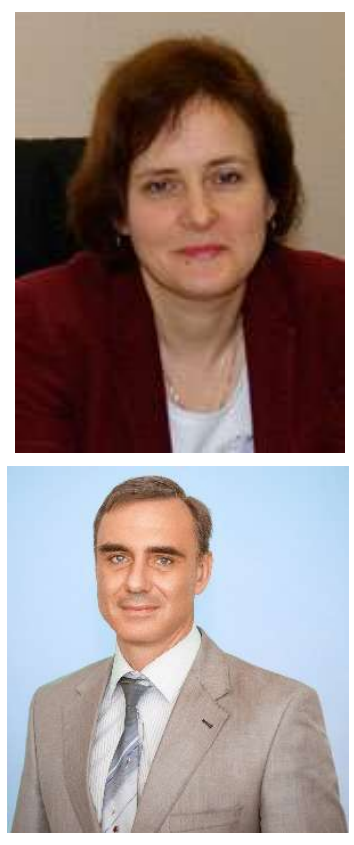

Славінська Олена Серхї̈вна, доктор технічних наук, професор, Національний транспортний університет, професор кафедри транпортного будівнищтва та управління майном, е-тail: elenaslavin9@gmail.com, тел.: +380509698109, Украӥна, 01010, Київ, вул. Омеляновича - Павленка 1,

https://orcid.org/0000-0002-9709-0078

Пруненко Дмитро Олександрович, кандидат економічних наук, дочент, Харківський національний університет міського господарства імені О.М. Бекетова, доцент кафедри транспортних систем і логістики, е-таil: prunenkod@rambler.ru, тел.: +380677311111, Україна, 61002, Харків, вул. Маршала Бажанова, 17,

https://orcid.org/orcid.org/0000-0001-7322-9998

Анотація. У статті визначені напрями моделювання впливу інтегрального показника формування та використання інтелектуального капіталу на узагальнюючи критерії конкурентоспроможності й інвестиційної привабливості будівельних підприємств. Встановлено високий рівень впливу інтегрального показника формування та використання інтелектуального капіталу на рівень конкурентоспроможності. Доведено, що інвестиційну привабливість на низькому рівні обумовлюють напрями формування та використання інтелектуального капіталу будівельних підприємств. Результати моделювання сформували основу для зростання рівня конкурентоспроможності й інвестиційної привабливості шляхом прийняття обгрунтованих управлінських рішень.

Ключові слова: інтелектуальний капітал, будівельні підприємства, формування та використання інтелектуального капіталу, конкурентоспроможність, інвестиційна привабливість.

Вступ. Результативними показниками, що характеризують діяльність будівельних підприємств $€$ узагальнюючи критерії конкурентоспроможності й інвестиційної привабливості. Поряд 3 цим, враховуючи міжнародний досвід та сучасні напрями розвитку економіки підприємств, зростає значення напрямів формування та використання інтелектуального капіталу. У цьому контексті виникає необхідність встановлення причинно-наслідкових зв'язків між узагальнюючими критеріями конкурентоспроможності й інвестиційної привабливості та інтегральним показником формування та використання інтелектуальним капіталом на будівельних підприємствах.

Науково-технічний збірник «АВТОмОБІльні дОРОГИ І дОРОЖнє БУдІВницТВО» http://addb.ntu.edu.ua ISSN 0365-8171 (Print), ISSN 2707-4080 (Online), ISSN 2707-4099 (CD).

AUTOMOBILE ROADS AND ROAD CONSTRUCTION, 2021. Issue 109 
Для вирішення поставленого завдання у дослідженні здійснюється моделювання впливу інтегрального показника формування та використання інтелектуального капіталу на узагальнюючи критерії конкурентоспроможності й інвестиційної привабливості будівельних підприємств шляхом застосування економетричного інструментарію, який базується на методах кореляційно-регресійного аналізу.

Мета і методи. Визначені напрями моделювання, які полягають у наступному:

1. Формування інформаційно-аналітичного забезпечення для проведення моделювання.

2. Побудова кореляційної матриці, що визначає зв'язки між інтегральним показником формування та використання інтелектуального капіталу та узагальнюючими критеріями конкурентоспроможності й інвестиційної привабливості будівельних підприємств.

3. Розробка моделей, що характеризують причинно-наслідкові зв'язки між інтегральним показником формування та використання інтелектуального капіталу та узагальнюючими критеріями конкурентоспроможності й інвестиційної привабливості будівельних підприємств.

4. Перевірка розроблених моделей на адекватність на основі застосування відповідних критеріїв.

5. Інтерпретація встановлених причинно-наслідкових зв'язків між інтегральним показником формування та використання інтелектуального капіталу та узагальнюючими критеріями конкурентоспроможності й інвестиційної привабливості будівельних підприємств.

Розглядаючи представлені напрями моделювання, слід відзначити, що формування інформаційно-аналітичного забезпечення здійснюється на основі результатів оцінки інтегрального показника формування та використання інтелектуального капіталу й узагальнюючих критеріїв конкурентоспроможності та інвестиційної привабливості будівельних підприємств.

Побудова кореляційної матриці, що визначає зв'язки між інтегральним показником формування та використання інтелектуального капіталу та узагальнюючими критеріями конкурентоспроможності й інвестиційної привабливості будівельних підприємств здійснюється шляхом застосування коефіцієнту парної кореляції.

На основі кореляційної матриці, що визначає зв'язки між інтегральним показником формування та використання інтелектуального капіталу та узагальнюючими критеріями конкурентоспроможності й інвестиційної привабливості будівельних підприємств встановлено:

посередній вплив інтегрального критерію формування та використання інтелектуального капіталу на узагальнюючий критерій конкурентоспроможності будівельних підприємств (коефіцієнт детермінації $\left(R^{2}\right)$ дорівнює 0,688$)$;

низький вплив інтегрального критерію формування та використання інтелектуального капіталу на узагальнюючий критерій інвестиційної привабливості $\left(R^{2}=0,0013\right)$;

низький рівень залежності між узагальнюючими критеріями конкурентоспроможності й інвестиційної привабливості $\left(R^{2}=0,01\right)$.

Розробка моделей, що характеризують причинно-наслідкові зв'язки між інтегральним показником формування та використання інтелектуального капіталу та узагальнюючими критеріями конкурентоспроможності й інвестиційної привабливості будівельних підприємств здійснювалось на основі застосування методу підстановки сутність якого полягає у покроковому включенні в модель факторів. Оскільки досліджується вплив інтегрального показника формування та використання інтелектуального капіталу на узагальнюючи критерії конкурентоспроможності та інвестиційної привабливості, то для побудови моделі лише здійснюється один крок. Результати побудови моделей представлені на рис. 1 2.

Модель залежності між інтегральним показником формування та використання інтелектуальним капіталом і узагальнюючим критерієм інвестиційної привабливості будівельних підприємств свідчить про низький зв'язок між ними.

Результати і пояснення. У результаті моделювання встановлено лінійний посередній зв'язок між інтегральним показником формування та використання інтелектуального капіталу і узагальнюючим критерієм конкурентоспроможності будівельних підприємств.

Науково-технічний збірник «АВтОмОБльні доРОГи І доРОжнє БУдІВництво» http://addb.ntu.edu.ua ISSN 0365-8171 (Print), ISSN 2707-4080 (Online), ISSN 2707-4099 (CD). AUTOMOBILE ROADS AND ROAD CONSTRUCTION, 2021. Issue 109 




Рисунок 1 - Графік та модель залежності між інтегральним показником формування та використання інтелектуальним капіталом і узагальнюючим критерієм конкурентоспроможності будівельних підприємств, відн. од.

Figure 1 - Schedule and model of dependence between the integral index of formation and use of intellectual capital and the general criterion of competitiveness of construction enterprises, rel. Units



Рисунок 2 - Графік та модель залежності між інтегральним показником формування та використання інтелектуального капіталу і узагальнюючим критерієм інвестиційної привабливості будівельних підприємств, відн. од.

Figure 2 - Schedule and model of dependence between the integral index of formation and use of intellectual capital and the general criterion of investment attractiveness of construction enterprises, rel. units

Перевірка розроблених моделей на адекватність здійснюється на основі відповідних критеріїв:

1. Коефіцієнт кореляції $(R)$, який характеризує рівень впливу незалежного показника (інтегральний показник формування та використання інтелектуального капіталу) на результуючі складові (узагальнюючі критерії конкурентоспроможності та інвестиційної привабливості будівельних підприємств). На основі значень коефіцієнта кореляції визначається напрям залежності. Зокрема, якщо визначено знак мінус, то встановлено обернений зв'язок, якщо плюс, то прямопропорційний. Залежно від значень коефіцієнту кореляції встановлюється рівень впливу між показниками:

0 - відсутній зв'язок;

0,01 - 0,25 - низький рівень впливу;

$0,251-0,5-$ посередній рівень;

$0,501-0,75-$ суттєвий рівень;

$0,751-0,99-$ високий рівень;

1 - абсолютний зв'язок.

2. Коефіцієнт детермінації визначається як квадрат від коефіцієнту кореляції і характеризує зв'язок між показниками.


ISSN 0365-8171 (Print), ISSN 2707-4080 (Online), ISSN 2707-4099 (CD).

AUTOMOBILE ROADS AND ROAD CONSTRUCTION, 2021. Issue 109 
3. Критерій Стьюдента $(t)$ визначає статистичну значущість показників розробленої моделі. Він оцінюється за співвідношенням:

$$
t=\frac{V_{1}-V_{2}}{\sqrt{v_{1}^{2}}+v_{2}^{2}},
$$

де $V_{1}$ - середні значення першої арифметичної порівнювальної сукупності; $V_{2}$ - середні значення другої арифметичної порівнювальної сукупності; $v_{1}$ - середні помилки першої арифметичної порівнювальної сукупності; $v_{2}$ - середні помилки другої арифметичної порівнювальної сукупності.

Показники є статистично значимими, якщо фактичне значення критерію Стьюдента перевищує його нормативне. У протилежному випадку, показник виключається із моделі.

4. Критерій Фішера $(F)$ визначається для підтвердження значущості коефіцієнтів кореляції, що показує надійність встановлених зв'язків між інтегральним показником формування та використання інтелектуального капіталу й узагальнюючими критеріями конкурентоспроможності та інвестиційної привабливості будівельних підприємств. Надійність встановлених зв'язків між показниками підтверджується, якщо фактичне значення критерію Фішера перевищує його нормативне. Якщо навпаки, то модель вважається неадекватною. Значення критерію Фішера визначається за співвідношенням:

$$
F=\frac{1-\eta^{2}}{n-p}
$$

де $\eta$ - кореляційне відношення, що характеризує зв'язки між інтегральним показником формування та використання інтелектуального капіталу й узагальнюючими критеріями конкурентоспроможності та інвестиційної привабливості будівельних підприємств; $p$ - параметри моделі регресії; $n$ - кількість спостережень, які застосовуються для моделювання.

5. Критерії перевірки на гомо або гетероскедастичність, які застосовуються для визначення однорідності або розгалуженості залишків випадкової величини. При цьому застосовуються тести Бройша-Пагана, Вайта, Гольфельда-Квандта, Глейзера, метод Ейткена.

6. Критерій Дарбіна - Уотсона (d) застосовується для визначення автокореляції залишків та визначається діапазонами значень, де охарактеризовані відповідні зони щодо мінімального й максимального його значень $\left(\mathrm{d}_{\mathrm{L}}\right.$ та $\left.\mathrm{d}_{\mathrm{U}}\right)$ :

якщо $d<d_{L}$, позитивна автокореляція - модель вважається неадекватною;

якщо $d>d_{U}$, то гіпотеза не відкидається - негативна автокореляція - модель адекватна;

якщо $d_{L}<d<d_{U}-$ зона невизначеності, де не можливо чітко визначити рівень автокореляції, виникає необхідність для проведення додаткових досліджень [1].

7. Критерії перевірки на мультиколінеарність, яка визначає ступень залежності між незалежними змінними. Сутність цього явища полягає у тому, що високий рівень залежності між незалежними показниками призводить до зміщення результатів оцінки й отримання недостовірних значень коефіцієнту кореляції. Перевірка на мультиколінеарність здійснюється на основі коефіцієнтів кореляції.

Результати визначення критеріїв адекватності представлені у табл. 1.

Результати визначення представлених критеріїв свідчать про адекватність моделі залежності між інтегральним показником формування та використання інтелектуальним капіталом і узагальнюючим критерієм конкурентоспроможності будівельних підприємств. 
Таблиця 1 - Результати визначення критеріїв адекватності моделі залежності між інтегральним показником формування та використання інтелектуальним капіталом і узагальнюючим критерієм конкурентоспроможності будівельних підприємств

Table 1 - The results of determining the criteria for the adequacy of the model of the relationship between the integral indicator of the formation and use of intellectual capital and the general criterion of competitiveness of construction enterprises

\begin{tabular}{|c|c|c|}
\hline $\begin{array}{c}\text { Назва крите- } \\
\text { рію }\end{array}$ & Значення критерію & Рівень адекватності \\
\hline $\begin{array}{c}\text { Коефіцієнт } \\
\text { кореляції }(R)\end{array}$ & 0,83 & $\begin{array}{l}\text { Високий рівень впливу інтегрального показника форму- } \\
\text { вання та використання інтелектуальним капіталом на уза- } \\
\text { гальнюючий критерій конкурентоспроможності будівель- } \\
\text { них підприємств. Визначає прямопропорційний зв'язок } \\
\text { між показниками. Збільшення інтегрального показника фо- } \\
\text { рмування та використання інтелектуальним капіталом при- } \\
\text { зводить до зростання узагальнюючого критерію конкурен- } \\
\text { тоспроможності будівельних підприємств і навпаки. Зміни } \\
\text { узагальнюючого критерію конкурентоспроможності на } \\
\text { 83\% обумовлені змінами інтегрального показника форму- } \\
\text { вання та використання інтелектуальним капіталом. }\end{array}$ \\
\hline $\begin{array}{l}\text { Коефіцієнт } \\
\text { детермінації } \\
\quad\left(R^{2}\right)\end{array}$ & 0,688 & $\begin{array}{l}\text { Суттєвий рівень впливу інтегрального показника форму- } \\
\text { вання та використання інтелектуального капіталу та узага- } \\
\text { льнюючого критерію конкурентоспроможності будівель- } \\
\text { них підприємств. }\end{array}$ \\
\hline $\begin{array}{l}\text { Критерій } \\
\text { Стьюдента } \\
\quad(t)\end{array}$ & $\begin{array}{c}\text { для постійної змінної: } \\
t_{\text {факт }}=28,72 \\
t_{\text {крит }}=3,25 \\
\text { для інтегрального пока- } \\
\text { зника формування та } \\
\text { використання інтелек- } \\
\text { туального капіталу: } \\
t_{\text {факт }}=33,94 \\
t_{\text {крит }}=3,25\end{array}$ & $\begin{array}{l}\text { Показники моделі статистично значимі, фактичні значення } \\
\text { критерію Стьюдента перевищують його критичні або нор- } \\
\text { мативні значення. }\end{array}$ \\
\hline $\begin{array}{l}\text { Критерій Фі- } \\
\text { шера }(F)\end{array}$ & $\begin{aligned} F_{\text {факт }} & =63,5 \\
F_{\text {крит }} & =5,32\end{aligned}$ & $\begin{array}{l}\text { Коефіцієнти кореляції значимі, фактичне значення крите- } \\
\text { рію Фішера перевищує його критичні або нормативні зна- } \\
\text { чення. }\end{array}$ \\
\hline $\begin{array}{c}\text { Критерій пе- } \\
\text { ревірки на } \\
\text { гомо або ге- } \\
\text { теро-скедас- } \\
\text { тичність }\end{array}$ & $\begin{array}{c}\text { для постійної змінної: } \\
t_{\text {факт }}=0,33 \\
t_{\text {крит }}=3,25 \\
\text { для інтегрального по- } \\
\text { казника формування та } \\
\text { використання інтелек- } \\
\text { туального капіталу: } \\
t_{\text {факт }}=0,12 \\
t_{\text {крит }}=3,25\end{array}$ & $\begin{array}{l}\text { Залишки показників розподілені однорідно, фактичні зна- } \\
\text { чення критерію Стьюдента менше критичного або норма- } \\
\text { тивного значення. }\end{array}$ \\
\hline $\begin{array}{l}\text { Критерій } \\
\text { Дарбіна - } \\
\text { Уотсона }(d)\end{array}$ & $\begin{array}{l}d=0,82 \\
d_{U}=1,32\end{array}$ & $\begin{array}{l}\text { Автокореляція залишків відсутня, оскільки розрахункове } \\
\text { значення критерію Дарбіна - Уотсона перевищує його мак- } \\
\text { симальне критичне значення. }\end{array}$ \\
\hline
\end{tabular}

Науково-технічний збірник «АВтОмОБІльні дОРОГИ І дОРОЖнє БУдІвницТвО» http://addb.ntu.edu.ua ISSN 0365-8171 (Print), ISSN 2707-4080 (Online), ISSN 2707-4099 (CD).

AUTOMOBILE ROADS AND ROAD CONSTRUCTION, 2021. Issue 109 
Кінець таб. 1

\begin{tabular}{|c|c|c|}
\hline $\begin{array}{c}\text { Назва крите- } \\
\text { рію }\end{array}$ & Значення критерію & Рівень адекватності \\
\hline $\begin{array}{c}\text { Критерії пе- } \\
\text { ревірки на } \\
\text { мультиколі- } \\
\text { неарність }\end{array}$ & не перевіряється & відсутня друга незалежна змінна. \\
\hline
\end{tabular}

Результати визначення критеріїв адекватності моделі залежності між інтегральним показником формування та використання інтелектуального капіталу і узагальнюючим критерієм інвестиційної привабливості будівельних підприємств представлені у табл. 2.

Таким чином, на основі дослідження визначено, що неадекватність моделі залежності між інтегральним показником формування та використання інтелектуального капіталу і узагальнюючим критерієм інвестиційної привабливості будівельних підприємств. Це підтверджує висновок про низький рівень впливу показника формування та використання інтелектуального капіталу на інвестиційну привабливість будівельних підприємств.

Таблиця 2 - Результати визначення критеріїв адекватності моделі залежності між інтегральним показником формування та використання інтелектуального капіталу і узагальнюючим критерієм інвестиційної привабливості будівельних підприємств

Table 2 - The results of determining the criteria of adequacy of the model of dependence between the integral indicator of the formation and use of intellectual capital and the general criterion of investment attractiveness of construction enterprises

\begin{tabular}{|c|c|c|}
\hline $\begin{array}{l}\text { Назва крите- } \\
\text { рію }\end{array}$ & Значення критерію & Рівень адекватності \\
\hline $\begin{array}{c}\text { Коефіцієнт } \\
\text { кореляції (R) }\end{array}$ & 0,036 & $\begin{array}{l}\text { низький рівень впливу інтегрального показника форму- } \\
\text { вання та використання інтелектуальним капіталом на уза- } \\
\text { гальнюючий критерій інвестиційної привабливості буді- } \\
\text { вельних підприємств. Визначає обернений зв'язок між по- } \\
\text { казниками. Збільшення інтегрального показника форм-- } \\
\text { вання та використання інтелектуальним капіталом приз- } \\
\text { водить до зменшення узагальнюючого критерію інвест-- } \\
\text { ційної привабливості будівельних підприємств і навпаки. } \\
\text { Це є аномальним і не відображає економічні напрями фо-- } \\
\text { рмування та використання показників. }\end{array}$ \\
\hline $\begin{array}{c}\text { Коефіцієнт } \\
\text { детермінації } \\
\left(\mathrm{R}^{2}\right)\end{array}$ & 0,0013 & $\begin{array}{l}\text { низький рівень впливу інтегрального показника форму- } \\
\text { вання та використання інтелектуального капіталу та уза- } \\
\text { гальнюючого критерію інвестиційної привабливості буді- } \\
\text { вельних підприємств. }\end{array}$ \\
\hline
\end{tabular}


Кінець таб. 2

\begin{tabular}{|c|c|c|}
\hline $\begin{array}{c}\text { Назва крите- } \\
\text { рію } \\
\end{array}$ & Значення критерію & Рівень адекватності \\
\hline $\begin{array}{c}\text { Критерій } \\
\text { Стьюдента (t) }\end{array}$ & $\begin{array}{c}\text { для постійної змінної: } \\
\mathrm{t}_{\text {факт }}=0,18 \\
\mathrm{t}_{\text {крит }}=3,25 \\
\text { для інтегрального по- } \\
\text { казника формування та } \\
\text { використання інтелек- } \\
\text { туального капіталу: } \\
\mathrm{t}_{\text {факт }}=0,67 \\
\mathrm{t}_{\text {крит }}=3,25\end{array}$ & $\begin{array}{l}\text { показники моделі статистично незначимі, фактичні зна- } \\
\text { чення критерію Стьюдента не перевищують його критичні } \\
\text { або нормативні значення. }\end{array}$ \\
\hline $\begin{array}{l}\text { Критерій Фі- } \\
\text { шера (F) }\end{array}$ & $\begin{array}{c}\mathrm{F}_{\text {факт }}=0,197 \\
\mathrm{~F}_{\text {крит }}=5,32\end{array}$ & $\begin{array}{l}\text { коефіцієнти кореляції незначимі, фактичне значення кри- } \\
\text { терію Фішера не перевищує його критичні або нормативні } \\
\text { значення. }\end{array}$ \\
\hline $\begin{array}{c}\text { Критерій пе- } \\
\text { ревірки на } \\
\text { гомо або ге- } \\
\text { теро-скедас- } \\
\text { тичність }\end{array}$ & - & $\begin{array}{l}\text { критерій перевірки на гомо або гетеро-скедастичність не } \\
\text { визначається, оскільки модель } є \text { неадекватною, встанов- } \\
\text { лені попередні критерії не мають статистичної значущо- } \\
\text { сті. }\end{array}$ \\
\hline $\begin{array}{l}\text { Критерій Дар- } \\
\text { біна - Уот- } \\
\text { сона (d) } \\
\end{array}$ & - & $\begin{array}{l}\text { критерій Дарбіна-Уотсона не визначається, оскільки мо- } \\
\text { дель } є \text { неадекватною, встановлені попередні критерії не } \\
\text { мають статистичної значущості. }\end{array}$ \\
\hline $\begin{array}{l}\text { Критерії пе- } \\
\text { ревірки на } \\
\text { мультиколі- } \\
\text { неарність }\end{array}$ & не перевіряється & відсутня друга незалежна змінна. \\
\hline
\end{tabular}

Інтерпретуючи отримані результати встановлено, що зростання інтегрального показнику формування та використання інтелектуального капіталу на $68 \%$ обумовлює збільшення узагальнюючого критерію конкурентоспроможності будівельних підприємств і навпаки. Поряд 3 цим, вплив інтегрального показника формування та використання інтелектуального капіталу всього на $0,13 \%$ обумовлює зміну узагальнюючого критерію інвестиційної привабливості. У таких умовах для подальшого дослідження щодо прогнозування змін застосовується модель, що характеризує залежність між інтегральним показником формування та використання інтелектуального капіталу і узагальнюючим критерієм конкурентоспроможності будівельних підприємств.

Результати прогнозування змін узагальнюючого критерію конкурентоспроможності будівельних підприємств залежно від зростання показника формування та використання інтелектуального капіталу представлено у табл. 3 .

У результаті дослідження визначено, що зростання показника формування та використання інтелектуального капіталу на 4\% і більше призведе до збільшення узагальнюючого критерію конкурентоспроможності на всіх будівельних підприємствах.

У результаті дослідження визначено, що зростання показника формування та використання інтелектуального капіталу на 4\% і більше призведе до збільшення узагальнюючого критерію конкурентоспроможності на всіх будівельних підприємствах. 
Таблиця 3 - Результати прогнозування змін узагальнюючого критерію конкурентоспроможності будівельних підприємств залежно від зростання показника формування та використання інтелектуального капіталу

Table 3- Results of forecasting changes in the general criterion of competitiveness of construction enterprises, depending on the growth rate of formation and use of intellectual capital

\begin{tabular}{|c|c|c|}
\hline 1 & 2 & 3 \\
\hline \multicolumn{3}{|c|}{ Зростання показника формування та використання інтелектуального капіталу на $1 \%$} \\
\hline ПАТ «Холдингова компанія «Київміськбуд» & 0,362 & 0,936 \\
\hline ПрАТ «Полтавський домобудівельний комбінат» & 0,318 & 1,188 \\
\hline ПАТ Трест «Житлобуд-1» & 0,36 & 0,943 \\
\hline ПАТ фірма «Галбуд» & 0,327 & 1,12 \\
\hline ДПАТ «Будівельна компанія «Укрбуд» & 0,321 & 1,164 \\
\hline ПАТ «Київське спеціалізоване ремонтно-будівельне товариство» & 0,299 & 1,39 \\
\hline $\begin{array}{l}\text { ПАТ «Українське спеціальне будівельно-монтажне підприємство } \\
\text { «Укрспецбудмонтаж» }\end{array}$ & 0,275 & 1,832 \\
\hline ПрАТ «Криворіжаглобуд» & 0,308 & 1,287 \\
\hline ПрАТ «Луцький домобудівельний комбінат» & 0,298 & 1,404 \\
\hline \multicolumn{3}{|c|}{ Зростання показника формування та використання інтелектуального капіталу на 2\% } \\
\hline ПАТ «Холдінгова компанія «Київміськбуд» & 0,372 & 0,962 \\
\hline ПрАТ «Полтавський домобудівельний комбінат» & 0,328 & 1,225 \\
\hline ПАТ Трест «Житлобуд-1» & 0,370 & 0,969 \\
\hline ПАТ фірма «Галбуд» & 0,337 & 1,155 \\
\hline ДПАТ «Будівельна компанія «Укрбуд» & 0,331 & 1,200 \\
\hline ПАТ «Київське спеціалізоване ремонтно-будівельне товариство» & 0,309 & 1,436 \\
\hline $\begin{array}{l}\text { ПАТ «Українське спеціальне будівельно-монтажне підприємство } \\
\text { «Укрспецбудмонтаж» }\end{array}$ & 0,285 & 1,899 \\
\hline ПрАТ «Криворіжаглобуд» & 0,318 & 1,329 \\
\hline ПрАТ «Луцький домобудівельний комбінат» & 0,308 & 1,451 \\
\hline \multicolumn{3}{|c|}{ Зростання показника формування та використання інтелектуального капіталу на 3\% } \\
\hline ПАТ «Холдінгова компанія «Київміськбуд» & 0,382 & 0,987 \\
\hline ПрАТ «Полтавський домобудівельний комбінат» & 0,338 & 1,262 \\
\hline ПАТ Трест «Житлобуд-1» & 0,380 & 0,996 \\
\hline ПАТ фірма «Галбуд» & 0,347 & 1,189 \\
\hline ДПАТ «Будівельна компанія «Укрбуд» & 0,341 & 1,236 \\
\hline ПАТ «Київське спеціалізоване ремонтно-будівельне товариство» & 0,319 & 1,483 \\
\hline $\begin{array}{l}\text { ПАТ «Українське спеціальне будівельно-монтажне підприємство } \\
\text { «Укрспецбудмонтаж» }\end{array}$ & 0,295 & 1,966 \\
\hline ПрАТ «Криворіжаглобуд» & 0,328 & 1,371 \\
\hline ПрАТ «Луцький домобудівельний комбінат» & 0,318 & 1,498 \\
\hline \multicolumn{3}{|c|}{ Зростання показника формування та використання інтелектуального капіталу на 4\% } \\
\hline ПАТ «Холдингова компанія «Київміськбуд» & 0,392 & 1,013 \\
\hline ПрАТ «Полтавський домобудівельний комбінат» & 0,348 & 1,3 \\
\hline
\end{tabular}


Кінець таб. 3

\begin{tabular}{|c|c|c|}
\hline 1 & 2 & 3 \\
\hline ПАТ Трест «Житлобуд-1» & 0,390 & 1,022 \\
\hline ПАТ фірма «Галбуд» & 0,357 & 1,223 \\
\hline ДПАТ «Будівельна компанія «Укрбуд» & 0,351 & 1,273 \\
\hline ПАТ «Київське спеціалізоване ремонтно-будівельне товариство» & 0,329 & 1,529 \\
\hline $\begin{array}{l}\text { ПАТ «Українське спеціальне будівельно-монтажне підприємство } \\
\text { «Укрспецбудмонтаж» }\end{array}$ & 0,305 & 2,032 \\
\hline ПрАТ «Криворіжаглобуд» & 0,338 & 1,413 \\
\hline ПрАТ «Луцький домобудівельний комбінат» & 0,328 & 1,546 \\
\hline \multicolumn{3}{|c|}{ Зростання показника формування та використання інтелектуального капіталу на 5\% } \\
\hline ПАТ «Холдингова компанія «Київміськбуд» & 0,402 & 1,039 \\
\hline ПрАТ «Полтавський домобудівельний комбінат» & 0,358 & 1,337 \\
\hline ПАТ Трест «Житлобуд-1» & 0,400 & 1,048 \\
\hline ПАТ фірма «Галбуд» & 0,367 & 1,257 \\
\hline ДПАТ «Будівельна компанія «Укрбуд» & 0,361 & 1,309 \\
\hline ПАТ «Київське спеціалізоване ремонтно-будівельне товариство» & 0,339 & 1,576 \\
\hline $\begin{array}{l}\text { ПАТ «Українське спеціальне будівельно-монтажне підприємс- } \\
\text { тво «Укрспецбудмонтаж» }\end{array}$ & 0,315 & 2,099 \\
\hline ПрАТ «Криворіжаглобуд» & 0,348 & 1,454 \\
\hline ПрАТ «Луцький домобудівельний комбінат» & 0,338 & 1,593 \\
\hline \multicolumn{3}{|c|}{ Зростання показника формування та використання інтелектуального капіталу на 10\% } \\
\hline ПАТ «Холдінгова компанія «Київміськбуд» & 0,452 & 1,168 \\
\hline ПрАТ «Полтавський домобудівельний комбінат» & 0,408 & 1,524 \\
\hline ПАТ Трест «Житлобуд-1» & 0,450 & 1,179 \\
\hline ПАТ фірма «Галбуд» & 0,417 & 1,429 \\
\hline ДПАТ «Будівельна компанія «Укрбуд» & 0,411 & 1,490 \\
\hline ПАТ «Київське спеціалізоване ремонтно-будівельне товариство» & 0,389 & 1,808 \\
\hline $\begin{array}{l}\text { ПАТ «Українське спеціальне будівельно-монтажне підприємс- } \\
\text { тво «Укрспецбудмонтаж» }\end{array}$ & 0,365 & 2,432 \\
\hline ПрАТ «Криворіжаглобуд» & 0,398 & 1,664 \\
\hline ПрАТ «Луцький домобудівельний комбінат» & 0,388 & 1,829 \\
\hline \multicolumn{3}{|c|}{ Зростання показника формування та використання інтелектуального капіталу на $15 \%$} \\
\hline ПАТ «Холдингова компанія «Київміськбуд» & 0,502 & 1,297 \\
\hline ПрАТ «Полтавський домобудівельний комбінат» & 0,458 & 1,710 \\
\hline ПАТ Трест «Житлобуд-1» & 0,500 & 1,310 \\
\hline ПАТ фірма «Галбуд» & 0,467 & 1,600 \\
\hline ДПАТ «Будівельна компанія «Укрбуд» & 0,461 & 1,671 \\
\hline ПАТ «Київське спеціалізоване ремонтно-будівельне товариство» & 0,439 & 2,041 \\
\hline $\begin{array}{l}\text { ПАТ «Українське спеціальне будівельно-монтажне підприємс- } \\
\text { тво «Укрспецбудмонтаж» }\end{array}$ & 0,415 & 2,766 \\
\hline ПрАТ «Криворіжаглобуд» & 0,448 & 1,873 \\
\hline ПрАТ «Луцький домобудівельний комбінат» & 0,438 & 2,065 \\
\hline
\end{tabular}

Науково-технічний збірник «АвтОмОБІльні дОРОГи г доРОжнє БУдІвницТвО» http://addb.ntu.edu.ua ISSN 0365-8171 (Print), ISSN 2707-4080 (Online), ISSN 2707-4099 (CD).

AUTOMOBILE ROADS AND ROAD CONSTRUCTION, 2021. Issue 109 
Висновки та рекомендації. На основі результатів моделювання інтегрального показника формування та використання інтелектуального капіталу на запропоновані заходи щодо зростання узагальнюючого критерію конкурентоспроможності й інвестиційної привабливості будівельних підприємств. Зокрема, основна увага фокусується на забезпеченні збільшення інтегрального показника формування та використання інтелектуального капіталу більш ніж на 4\% для зростання рівня конкурентоспроможності. У контексті формування та використання інтелектуального капіталу запропоновано змінити траєкторію й підходи його застосування для забезпечення інвестиційної привабливості будівельних підприємств.

Таким чином, здійснено моделювання впливу інтегрального показника формування та використання інтелектуального капіталу на узагальнюючи критерії конкурентоспроможності й інвестиційної привабливості, що дозволило формалізувати зв'язки між представленими показниками і розробити заходи для їх зростання у контексті забезпечення розвитку будівельних підприємств.

Перелік посилань

1. Критерій Дарбіна - Уотсона. [Електронний ресурс]. - Режим доступа: https://uk.wikipedia.org/wiki/Критерій_Дарбіна-Уотсона.

\section{SIMULATION OF THE INFLUENCE OF THE INTEGRAL INDICATOR FOR FORMATION AND USE OF INTELLECTUAL CAPITAL ON THE GENERALIZED CRITERION OF COMPETITIVENESS AND INVESTMENT ATTRACTIVENESS OF CONSTRUCTION COMPANIES}

Slavinska Olena Serhiyivna, Doctor of Technical Sciences, Professor, National Transport University, Professor of the department of Transport construction and property management, e-mail: elenaslavin9@gmail.com, tel.: +380509698109, Ukraine, 01010, Kyiv, Omelyanovicha - Pavlenko str., 1, http://orcid.org/0000-0002-9709-0078.

Prunenko Dmytro Oleksandrovych, $\mathrm{PhD}$, associate professor, O. M. Beketov National University of Urban Economy in Kharkiv, associate professor of the department of Transport systems and logistics, e-mail: prunenkod@rambler.ru, tel.: +380677311111, Ukraine, 61002 Kharkiv, Marshal Bazhanov str, 17, http://orcid.org/0000-0001-7322-9998

Summary.The article defines the directions of modeling the influence of the integral indicator of the formation and use of intellectual capital on generalizing criteria of competitiveness and investment attractiveness of construction enterprises. A high level of influence of the integral indicator of the formation and use of intellectual capital on the level of competitiveness is established. It is proved that the investment attractiveness at a low level is determined by the directions of formation and use of the intellectual capital of construction enterprises. The results of modeling have formed the basis for the growth of the level of competitiveness and investment attractiveness through the adoption of sound management decisions.

Key words: intellectual capital, construction companies, formation and use of intellectual capital, competitiveness, investment attractiveness.

\section{References}

1. Kryteriy Darbina-Uotsona [The Darwin-Watson Criterion]. Available at: https://uk.wikipedia.org/wiki/Kryteriy Darbina-Uotsona [in Ukrainian]. 